\title{
The flake graphite prospect of Piippumäki-an example of a high-quality graphite occurrence in a retrograde metamorphic terrain in Finland
}

\author{
J Palosaari $^{1} \cdot$ R-M Latonen ${ }^{2} \cdot \mathrm{J}^{-H}$ Smått $^{3} \cdot$ S Raunio $^{4} \cdot$ O Eklund $^{1}$ \\ Received: 21 January 2019 / Accepted: 3 March 2020 / Published online: 8 April 2020 \\ (C) The Author(s) 2020
}

\begin{abstract}
The flake graphite occurrence in Piippumäki, Eastern Finland, as indicated by an airborne electromagnetic anomaly, was located during fieldwork by electromagnetic measurements with Slingram. The anomaly is approximately $0.1 \times 1 \mathrm{~km}$ in size. The flake graphite is hosted by quartz-feldspar gneiss and amphibolite that have been subjected to retrograde metamorphism. This is observed in thin sections as granulite facies (garnet + cordierite + sillimanite + melt) regressing to greenschist facies (epidote, chlorite, albite, and white mica). The graphite (up to $1 \mathrm{~mm}$ large flakes) is found in graphite-bearing layers in the gneiss, and to a minor extent disseminated in the amphibolite. The average total sulfur (TS) is $0.33 \%$, total carbon (TC) is $6.49 \%$, and the average content of graphitic carbon $(\mathrm{Cg})$ is $6.41 \%$ for the analyzed graphite-bearing rocks. SEM, XRD, and Raman spectroscopy were used for analyzing the flake graphite, indicating that the graphite is almost defect-free, of high quality, and has not been affected by the retrograde metamorphism. The peak metamorphic temperature of $737^{\circ} \mathrm{C}$ was determined by a Raman thermometer, and no temperatures of greenschist facies were observed. A pseudosection was constructed from whole-rock chemical composition and indicated equilibration at ca $5 \mathrm{kbar}$ and $740{ }^{\circ} \mathrm{C}$, which corresponds to the observed mineral assemblages.
\end{abstract}

Keywords Flake graphite $\cdot$ Raman spectroscopy $\cdot$ Retrograde metamorphism $\cdot$ Fennoscandian shield

\section{Introduction}

Natural graphite has been listed as a critical raw material by the European Union since 2011 (European Commission 2017a). As the demand of natural graphite is increasing in the EU, it is important to identify high-quality graphite

Editorial handling: P. Peltonen

Electronic supplementary material The online version of this article (https://doi.org/10.1007/s00126-020-00971-z) contains supplementary material, which is available to authorized users.

J Palosaari

jenny.palosaari@gmail.com

1 Geology and Mineralogy, Åbo Akademi University, FI-20500 Turku, Finland

2 Laboratory of Analytical Chemistry, Åbo Akademi University, FI-20500 Turku, Finland

3 Laboratory of Physical Chemistry, Åbo Akademi University, FI-20500 Turku, Finland

4 Oy Fennoscandian Resources Ab, Turku, Finland occurrences. In 2010-2014, China was the biggest producer of natural graphite in the world producing $69 \%$ while Europe produced only 1\% (European Commission 2017b). Graphite is a versatile material and is used, e.g., in batteries and refractories due to its high electrical conductivity and heat resistance (Beyssac and Rumble 2014). Graphite is composed of sheets of graphene, which are one carbon atom thick, and is a very soft mineral due to the weak van der Waals forces between the graphene sheets. The graphene sheets themselves are durable, owing to the covalent bonds between the carbon atoms in their hexagonal structure. Graphitic carbon appears in different geological settings and forms either through graphitization of organic matter or by deposition from carbon-saturated fluids (Beyssac and Rumble 2014).

An extensive part of the Fennoscandian shield consists of the Svecofennian domain characterized by amphibolite to granulite facies metamorphic bedrock. Since high quality of graphite can be related to high grade metamorphism, supracrustal rocks of the Svecofennian domain are a promising target for high-quality flake graphite deposits. Graphite occurrences in Fennoscandia have been studied quite extensively, e.g., by Gautneb and Tveten (2000), Pearce et al. 
(2015), Palosaari et al. (2016a), and Rønning et al. (2018). Several projects regarding graphite exploration were active in 2016 in Norway, Sweden, and Finland (Gautneb 2016). For the time being, the only active graphite mine in Fennoscandia is Skaland Graphite AS in Norway. The mining activity at Woxna graphite mine in Sweden ceased in 2015 (Leading Edge Materials 2018). Although graphite is a common mineral in metamorphosed supracrustal sequences and in the Finnish bedrock, graphite deposits of economic interest are uncommon. Graphite occurrences in Finland have been extensively explored and mapped by the Geological survey of Finland for use in energy production during the 1980s (e.g., Sarapää and Kukkonen 1984a; Sarapää and Kukkonen 1984b; Ahtola and Kuusela 2015), and were later explored for flake graphite ores and for flake graphite production (Palosaari et al. 2016b; Beowulf Mining plc 2019). In addition, a few mining companies have investigated the flake graphite finding in Piippumäki (Nurmela 1989). Kärpälä is another graphite deposit near Piippumäki where the ore was exploited during the late nineteenth century (Puustinen 2003). Piippumäki is ideal for studying graphite because the graphite is found in outcrop and thus easy to access. We chose to study Piippumäki based on previous studies in the area and comparison of the metamorphic map (Hölttä and Heilimo 2017) with the map of black shales in Finland (Arkimaa et al. 2000).

In order to characterize the graphite in Piippumäki and to understand its behavior in metamorphic processes, we used thin sections, SEM, XRD, and Raman spectroscopy. At the research site, we conducted fieldwork and electromagnetic measurements with Slingram, which is an electromagnetic instrument used for detecting conductive layers in the ground. In this study, we define the geological environment for the flake graphite finding and the suitability of the graphite present for technical applications. We use Piippumäki as an example but argue that our findings are applicable for any other area with graphite in high grade metamorphic rocks.

\section{Geological setting}

The study area of Piippumäki is situated in the northern part of the Southern Finland Subprovince (SFS) of the Svecofennian province (Nironen et al. 2016), $50 \mathrm{~km}$ southwest of the town of Mikkeli (Fig. 1). The area is approximately $0.5 \times 1 \mathrm{~km}$ in size. The largest graphite deposit in Finland (Kärpälä) is situated $5 \mathrm{~km}$ northeast of Piippumäki. It was exploited until 1947 for industrial purposes.

The rocks in Piippumäki are Paleoproterozoic in age and were formed during the Svecofennian orogeny when the arc complexes Western Finland, and Southern Finland docked to the Archean continent (Nironen 2017). The sediments were deposited off the coast of the Archean continent and were subsequently metamorphosed during the orogeny
(Kähkönen 2005). The metamorphism took place at 1.88$1.79 \mathrm{Ga}$ and reached upper amphibolite and granulite facies at 4-6 kbar. The rocks close to the northern border of the SFS comprise andalusite schists and sillimanite gneisses (Hölttä and Heilimo 2017).

The dominating rocks in the study area are migmatitic garnet-, cordierite-, and sillimanite-mica schists and gneisses. Amphibolite and quartz-feldspar gneiss appear as layers. Graphite- and sulfide-rich layers are also present. The graphite-rich layers can be up to a few meters thick (Simonen 1982). Diopside-bearing quartz-feldspar gneiss and diopside-amphibolite are also found here. The gneisses and schists strike E-W and predate plutonic rocks in the area (microcline granite), based on the contact relations observed. A cross section by Simonen (1982) shows that quartz-feldspar gneisses and the associated amphibolites lie in the middle of anticlines and therefore stratigraphically lie beneath the mica gneisses. This also indicates that Piippumäki is part of an anticline (Simonen 1982). A strong electromagnetic (EM) anomaly, interpreted as black shale, is observed across the study area in Piippumäki (Mineral Deposits and Exploration, n.d., Geological Survey of Finland, Hyvönen et al. 2013). The conductor continues towards Kärpälä graphite deposit.

In order to determine the origin of the graphite, Rankama (1948) analyzed the ${ }^{12} \mathrm{C} /{ }^{13} \mathrm{C}$ ratio in graphite from Kärpälä and suggested that the graphite is organic in origin, based on the average ${ }^{12} \mathrm{C} /{ }^{13} \mathrm{C}$ ratio of 91.7 (corresponds to $\delta^{13} \mathrm{C}$ of 29.6). Rankama (1948) also suggested that the graphite in Kärpälä has originally been a layer of bituminous sediment that was deformed into a lenticular graphite deposit. According to Simonen (1982), the graphite formed during metamorphism from organic matter in sediments.

\section{Materials and methods}

For this work, we collected 48 samples and analyzed the graphite quality, metamorphic grade, and petrography in 34 of them (Fig. 2). We also sampled the waste rock pile in the vicinity of Kärpälä. We analyzed both thin sections and individual graphite flakes of the samples by SEM, XRD, and Raman spectroscopy (Online Resource 1). Carbon and sulfur content in the samples was analyzed by TD-MS, CS, and IR by Actlabs Ltd. (Table 1). Whole-rock chemical composition analyzed with XRF at Åbo Akademi University was used for constructing the pseudosection (Table 1). Besides geological mapping, we performed electromagnetic ground measurements with Slingram. The study area is mostly covered by sandy till, but some of the graphite-bearing rocks are accessed in old excavated pits. 

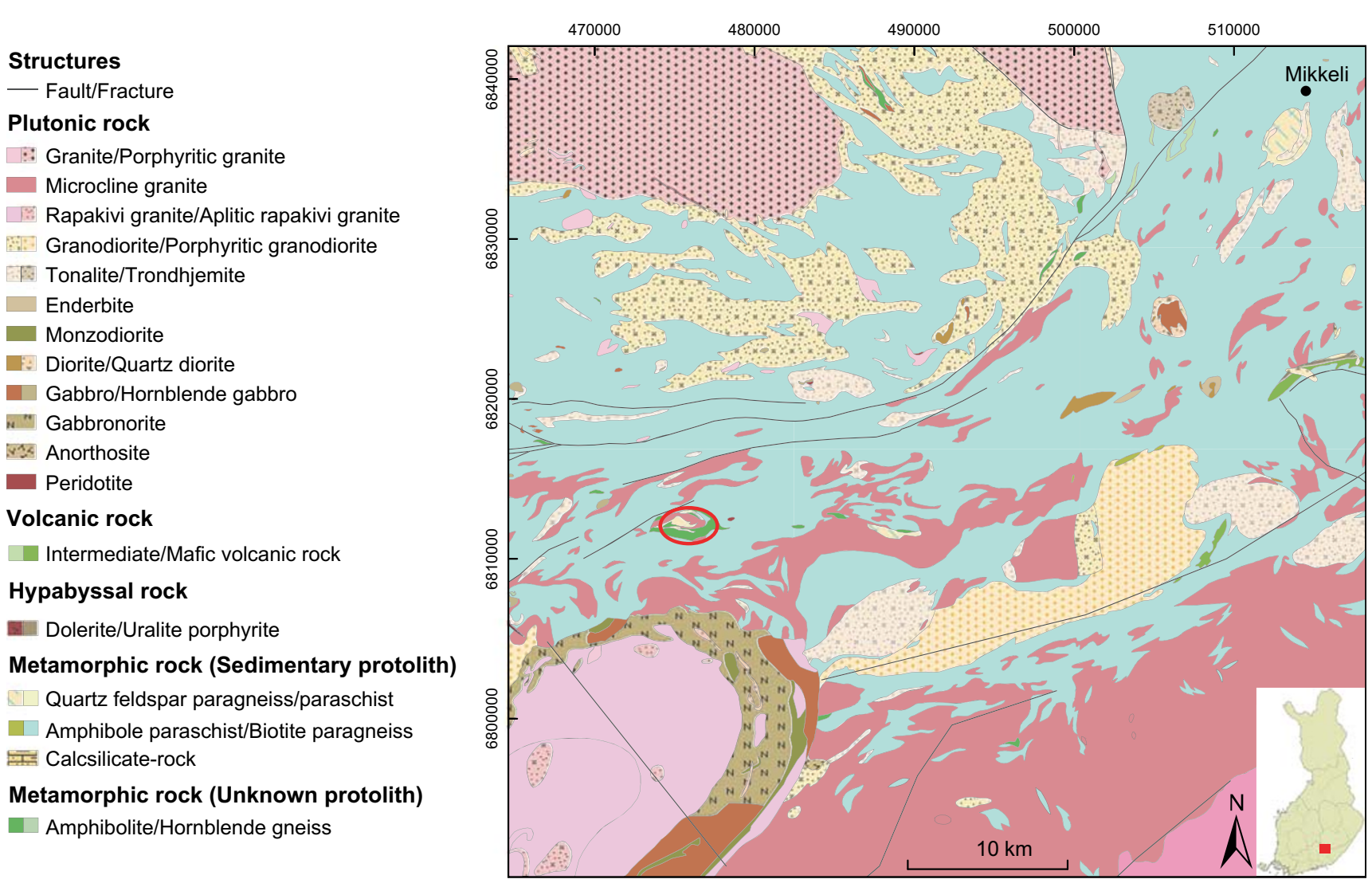

Fig. 1 Overview of the bedrock surrounding the study area of Piippumäki, which is indicated by the circle, ca $50 \mathrm{~km}$ from Mikkeli. Modified from the digital geological map database of Finland (DigiKP, Geological Survey of Finland 2017)

\section{Slingram}

Slingram was used for locating the conductive graphite layers accurately, and we performed the measurements perpendicular to the foliation with a measurement frequency of $3600 \mathrm{~Hz}$ and coil separation of $60 \mathrm{~m}$. We measured a total of 47 parallel lines with Slingram with a $50-\mathrm{m}$ line separation where the conducting layer is strongest, and a $100-\mathrm{m}$ line separation at the easternmost lines where the conductor is weaker (Fig. 3). The lines are ca $200 \mathrm{~m}$ in length, aiming to cross the boundaries of the conductor.

\section{Scanning electron microscopy}

We examined the appearance of graphite flakes and possible impurities with SEM at the Laboratory of Inorganic Chemistry at Åbo Akademi University both in thin sections and individual graphite flakes (20 samples in total, see Online Resource 1). A LEO Gemini 1530 FEG-SEM instrument equipped with a ThermoNoran X-ray detector was used. Energy dispersive $\mathrm{X}$-ray analysis (EDXA, Ultradry) was used for elemental analysis. We picked out individual graphite flakes directly from samples and washed them. No additional conductive layer was needed when examining the graphite flakes.

\section{X-ray diffraction}

To characterize the crystalline nature of the flake graphite samples and to identify potential impurities, we used XRD. We performed the measurements with a Bruker D8 Discover instrument, located at the Laboratory of Physical Chemistry at Åbo Akademi University, on four different samples (404804, $404805,404806,404812$ ) using a HI-STAR 2-D detector. The wavelength used was a weighted average of $\mathrm{Cu}-\mathrm{K} \alpha 1$ and $\mathrm{Cu}-$ $\mathrm{K} \alpha 2$ (and $\mathrm{Cu}-\mathrm{K} \beta$ ): $1.5418 \AA$ (Bragg-Brentano). The results are presented in diffractograms with the scattering angle $(2 \theta)$ on the $x$-axis and the intensity on the $y$-axis. The intensities of the diffractograms have been normalized based on the (002) graphite reflection.

\section{Raman spectroscopy}

We investigated the quality of graphite, as well as possible lattice defects, using Raman spectroscopy. Using the calibration of Rahl et al. (2005), we estimated peak metamorphic temperatures in graphite from the Raman results. The Raman spectra were recorded at the Laboratory of Analytical Chemistry at Åbo Akademi University using a Renishaw Ramascope (system 1000) equipped with a Leica DMLM microscope connected to a CCD camera. The measurements were made by using an 


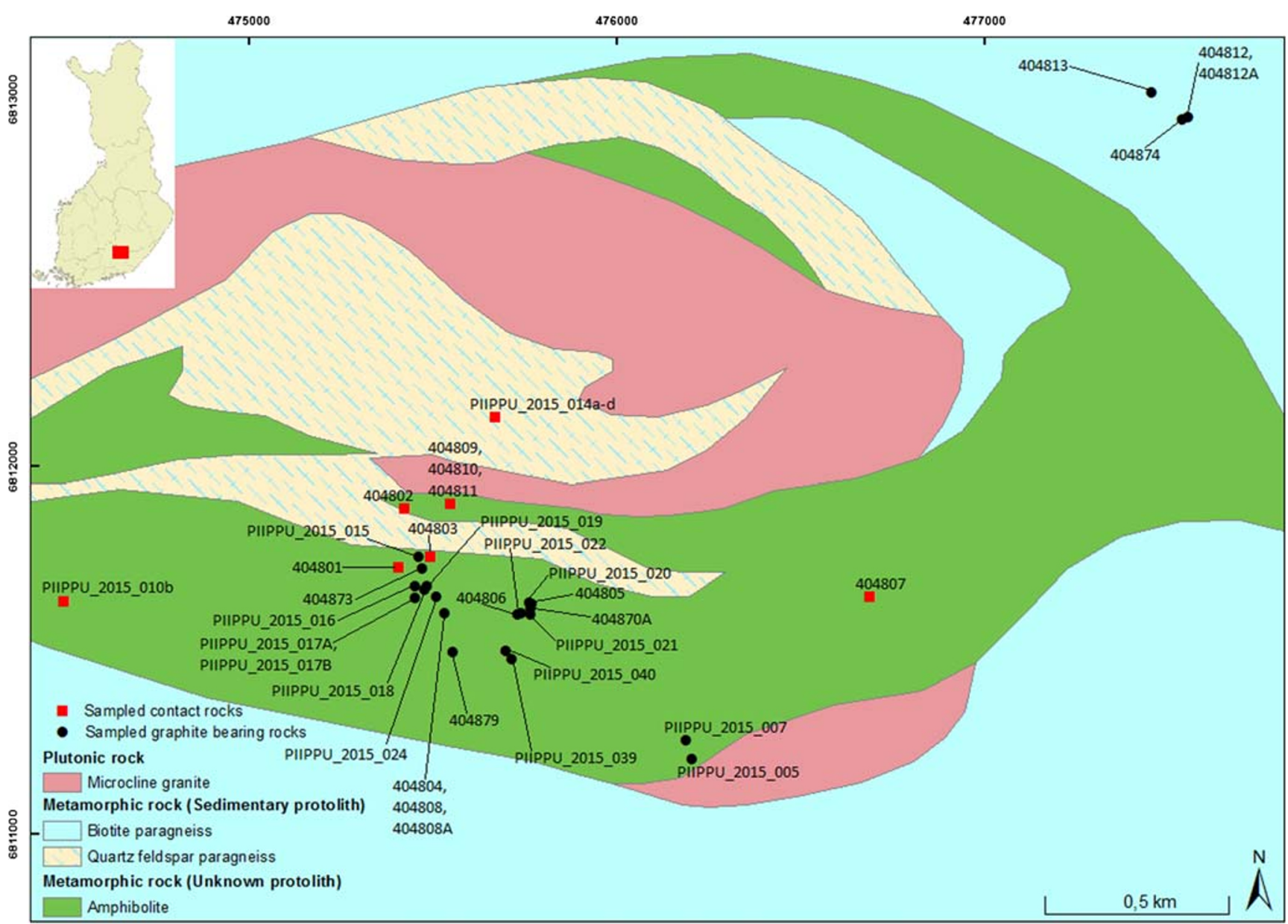

Fig. 2 Bedrock map of the study area with the sample locations. Red squares indicate contact rocks (amphibolite and quartz-feldspar gneiss) and black circles indicate graphite-bearing rocks. The graphite is hosted by metasedimentary layers within the amphibolite. The samples in the NE

Ar-ion laser (LaserPhysics) with the excitation wavelength of $514 \mathrm{~nm}$ on a ca $\varnothing 2-\mu \mathrm{m}$ surface area with a laser power of $20 \mathrm{~mW}$. The spectrometer was calibrated against a Si standard $\left(520.0 \mathrm{~cm}^{-1}\right)$. We performed measurements on 11 different part of the map are sampled near the old graphite mine Kärpälä. Modified from the digital geological map database of Finland (DigiKP, Geological Survey of Finland 2017)

graphite flake samples, which were either in thin sections or individual hand-picked grains (see Online Resource 1). The measurements were made parallel to the $C$-axis on the graphite grains (perpendicular to the graphene sheets in graphite) and

Table 1 Whole-rock chemical composition for a quartz-feldspar gneiss and total C and S for graphite-bearing rocks from Piippumäki. Sample 404811 was analyzed with XRF at Åbo Akademi University, and the rest were analyzed by Actlabs Ltd

\begin{tabular}{|c|c|c|c|c|c|c|c|c|c|c|c|}
\hline Sample no. & $\mathrm{SiO}_{2}$ & $\mathrm{TiO}_{2}$ & $\mathrm{Al}_{2} \mathrm{O}_{3}$ & $\mathrm{FeO}$ & $\mathrm{MnO}$ & $\mathrm{MgO}$ & $\mathrm{CaO}$ & $\mathrm{Na}_{2} \mathrm{O}$ & $\mathrm{K}_{2} \mathrm{O}$ & $\mathrm{H}_{2} \mathrm{O}$ & Total \\
\hline \multirow[t]{2}{*}{404811} & 59.74 & 1.48 & 15.32 & 12.31 & 0.17 & 3.57 & 1.78 & 2.16 & 1.89 & 1.54 & 99.96 \\
\hline & \multicolumn{3}{|c|}{ Total C (\%) } & & \multicolumn{3}{|c|}{ Total S (\%) } & & \multicolumn{3}{|c|}{ C-graph (\%) } \\
\hline PIIPPU_2015_019 & \multicolumn{3}{|l|}{4.56} & & \multicolumn{3}{|l|}{1.66} & & \multicolumn{2}{|l|}{4.66} & \\
\hline PIIPPU_2015_016 & \multicolumn{3}{|l|}{5.32} & & \multicolumn{3}{|l|}{0.09} & & \multicolumn{2}{|l|}{5.13} & \\
\hline PIIPPU_2015_017A & \multicolumn{3}{|l|}{2.96} & & \multicolumn{3}{|l|}{0.06} & & \multicolumn{2}{|l|}{2.91} & \\
\hline PIIPPU_2015_017B & \multicolumn{3}{|l|}{3.02} & & \multicolumn{3}{|l|}{0.07} & & \multicolumn{2}{|l|}{2.91} & \\
\hline PIIPPU_2015_020 & \multicolumn{3}{|l|}{9.67} & & \multicolumn{3}{|l|}{0.3} & & \multicolumn{2}{|l|}{9.5} & \\
\hline PIIPPU_2015_022 & \multicolumn{3}{|l|}{9.12} & & \multicolumn{3}{|l|}{0.23} & & \multicolumn{2}{|l|}{9.05} & \\
\hline PIIPPU_2015_024 & \multicolumn{3}{|l|}{2.43} & & \multicolumn{3}{|l|}{0.15} & & \multicolumn{2}{|l|}{2.39} & \\
\hline 404870A & \multicolumn{3}{|l|}{14.8} & & \multicolumn{3}{|l|}{0.09} & & \multicolumn{2}{|l|}{14.7} & \\
\hline
\end{tabular}




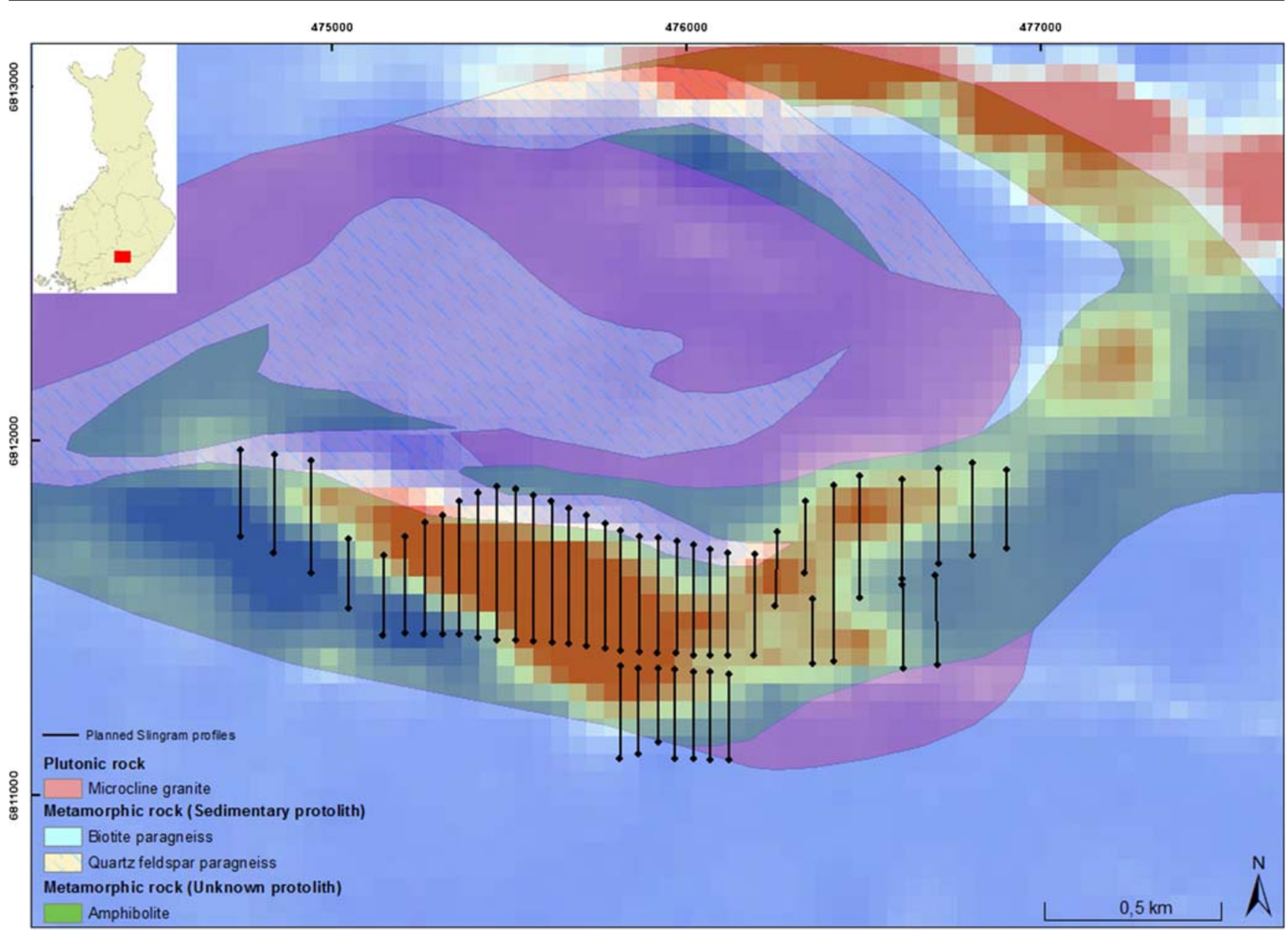

Fig. 3 Map showing the planned Slingram lines in Piippumäki in reference to the airborne geophysical measurements. Red indicates high conductivity, blue indicates low conductivity. Modified from the digital geological map database of Finland (DigiKP, Geological Survey of Finland 2017)

perpendicular to the $C$-axis on graphite in thin sections. The results from Raman spectroscopy measurements are presented by spectra with the wavenumber (Raman shift) on the $x$-axis and the intensity on the $y$-axis. The obtained spectra consist of first- and second-order regions, $1100-1800 \mathrm{~cm}^{-1}$ and 2500 $3100 \mathrm{~cm}^{-1}$, respectively (Beyssac et al. 2002).

In total, 8 samples (see Online Resource 1) were measured for the temperature estimates, which are based on a mean value of five measurements on each sample. The peak temperature estimates are based on peak areas and peak heights. The areas of the peaks were determined by using the Lorentzian function in Origin 2015 by OriginLab Co. We chose the calibration of Rahl et al. (2005), which is based on the equation of Beyssac et al. (2002), for the temperature estimations in this study because it is suitable for a broader temperature range of $100-700{ }^{\circ} \mathrm{C}$ compared with $330-650{ }^{\circ} \mathrm{C}$ $\pm 50{ }^{\circ} \mathrm{C}$ of Beyssac et al. (2002). We used $\mathrm{T}\left({ }^{\circ} \mathrm{C}\right)=737+$ $320(R 1)-1067(R 2)+80.638(R 1)^{2}$ to calculate the metamorphic temperatures. In this equation, $R 1=\left(\frac{D 1}{G}\right)_{H}$, where the subscript $\mathrm{H}$ refers to the height of the bands D1 and G, and
$R 2=\left(\frac{D 1}{G+D 1+D 2}\right)_{A}$, where the subscript A refers to the area of the bands D1, D2, and G. The maximum temperature that can be calculated with this method is $737^{\circ} \mathrm{C}$.

\section{Results}

\section{Fieldwork}

We made field observations on graphite-bearing rocks, primarily in test trenches dug by the Rautaruukki company in 1985. The trenches lie perpendicular to the foliation. When examining the trenches, we found some new outcrops with graphite. The main rocks in the research area are quartzfeldspar gneiss and amphibolite. The geological map in Fig. 2 shows the locations of the sampled material, and the samples are divided into graphite-bearing rocks and contact rocks. The quartz-feldspar gneiss is of sedimentary origin and is the host rock of the graphite-bearing layers, with layers of amphibolite 
also being present. The gneiss consists mainly of mediumgrained quartz and feldspar with abundant biotite. The gneiss shows distinct foliation, and at some places it is affected by partial melting. Sillimanite is present in the leucosome. Sulfides are present in the mica- and graphite-rich layers, which appears as a rusty surface in outcrop. The protolith of the Piippumäki amphibolite is unknown. It is diopside-bearing and has hornblende, quartz, and plagioclase as main minerals. The rock is gray to dark gray in color, fine-grained, and banded, and at some places boudins are present. Minor graphite dissemination is observed in some places.

The graphite is present in the quartz-feldspar gneiss as layers and is also disseminated to a minor extent in the host rock and the amphibolite. At contacts between the graphitebearing rock and the host rock, graphite is usually found concentrated along the contacts. Graphite is present as large flakes, mainly $<1 \mathrm{~mm}$. Graphite flakes $>180 \mu \mathrm{m}$ are considered large (Northern Graphite 2019). Observations from the test trenches indicate that the electromagnetic anomaly is caused by the graphite-rich layers in the quartz-feldspar gneisses.

In general, the lithological units in Piippumäki dip $75-85^{\circ}$ and strike W-E. In the eastern parts of Piippumäki, the foliation changes slightly towards NE. The measured fold axis in Piippumäki dips ca $60^{\circ}$ towards NW, NE, and SW. This indicates that the area is the top of an anticline, as suggested by Simonen (1982).

The observed structures correspond well to the electromagnetic anomalies in the area. The airborne electromagnetic map correlates with our results from the ground measurements with Slingram. The graphite observations conform to the electromagnetic map produced from the data of the Slingram measurements (showing the conductivity anomaly) (Fig. 4). The anomaly is ca $1-\mathrm{km}$ long and $100-\mathrm{m}$ wide, and curves across the area towards NW and NE.

\section{Petrography}

The Piippumäki gneisses are composed of quartz, plagioclase, biotite, and graphite (Fig. 5). Pyrite is also present in small amounts $(1-2 \%)$. The biotite and graphite are parallel to the foliation of the gneiss. The gneiss is fine-grained and equigranular, but medium-grained at migmatitic parts. The quartz grains show undulose extinction, which indicates that the mineral has undergone deformation. Graphite is disseminated in the rock as flakes and irregular grains (Fig. 5a). In places, the graphite is present as mixed grains together with chloritized biotite (Fig. 5b). In these mixed grains, the graphite is more irregular and deformed.

The metamorphic indicator minerals garnet, cordierite, and sillimanite are present in the quartz-feldspar gneisses. Garnet is found in sample 404811, sillimanite and cordierite in sample PIIPPU_2015_014d. Sample 404811 is a quartz-feldspar gneiss with quartz and feldspar as the main minerals. Biotite (partly chloritized) is also abundant. The garnets are not fully isotropic (Fig. 6), indicating that alteration from garnet to cordierite has started. The matrix in sample PIIPPU 2015 014d consists primarily of microcline and quartz with veins of sillimanite, and minor cordierite and biotite (Fig. 7a, b, c, d). Cordierite appears with distinct patchy twinning and at some places with cracks filled with pinite. The alteration from garnet to cordierite is also visible in the thin section (Fig. 7c, d).

Amphibolite is the immediate host rock of the graphitebearing metasedimentary layers, and is composed of hornblende, diopside, quartz, and plagioclase, with accessory minerals biotite, sulfide, and sericite. The amphibolite is banded and foliated, and the grain size is fine to medium. Samples 404801 and 404809 represent the amphibolites in Piippumäki. In sample 404801, the amphibole is pleochroic brown, while in 404809, it is pleochroic green (Fig. 8). Sample 404809 is diopside-bearing (Fig. 8c, d), green, and banded.

\section{Whole-rock chemical composition}

One sample was analyzed for whole-rock chemical composition and eight samples for graphitic carbon and sulfur content. The results show that the carbon in the samples is graphitic carbon. The amounts of total carbon range from 2.43 to $14.8 \%$ $\mathrm{C}$, graphitic carbon from 2.39 to $14.7 \mathrm{wt} \% \mathrm{Cg}$ (average $6.4 \mathrm{wt} \% \mathrm{C}$ ), and total sulfur from 0.06 to $1.66 \mathrm{wt} \% \mathrm{~S}$ (average $0.33 \mathrm{wt} \%$ S) (Table 1).

High-T/low-P metamorphism in the rocks of the Piippumäki area is indicated by the paragenesis garnet - cordierite - sillimanite + melt, and no orthopyroxene is observed in the samples. This indicates temperatures around $750{ }^{\circ} \mathrm{C}$ and pressures around $5 \mathrm{kbar}$. This granulite facies assemblage is overprinted by epidote, chlorite, and white mica (pyrophyllite, as determined by SEM and EDX) indicating greenschist metamorphism with temperatures not higher than $400{ }^{\circ} \mathrm{C}$. To examine the $\mathrm{P} / \mathrm{T}$ field for the investigated area, a pseudosection based on whole-rock chemical composition of sample 404811 (Table 1) was constructed with the Perple_X version 6.8.5. Calculations involved the phases biotite (bt), sanidine (sa), white mica (mica), melt, garnet (grt), orthopyroxene (opx), staurolite (st), cordierite (crd), chloritoid (cld), spinel (spl), ilmenite (ilm), and plagioclase (pl). The activity model used for biotite is from Tajcmanová et al. (2009); for sanidine from Waldbaum and Thompson (1968); for white mica from Auzanneau et al. (2010) and Coggon and Holland (2002); for melt from Holland and Powell (2001) and White et al. (2001); for garnet from Holland and Powell (1998); for orthopyroxene from Holland and Powell (1996); for chloritoid from White et al. (2000); and for plagioclase from Newton et al. (1980). The $\mathrm{H}_{2} \mathrm{O}$ content of $1.54 \mathrm{wt} \%$ was calculated from the mineral mode, assuming that all water in the rock was in biotite. The paragenesis garnet - cordierite - biotite - 


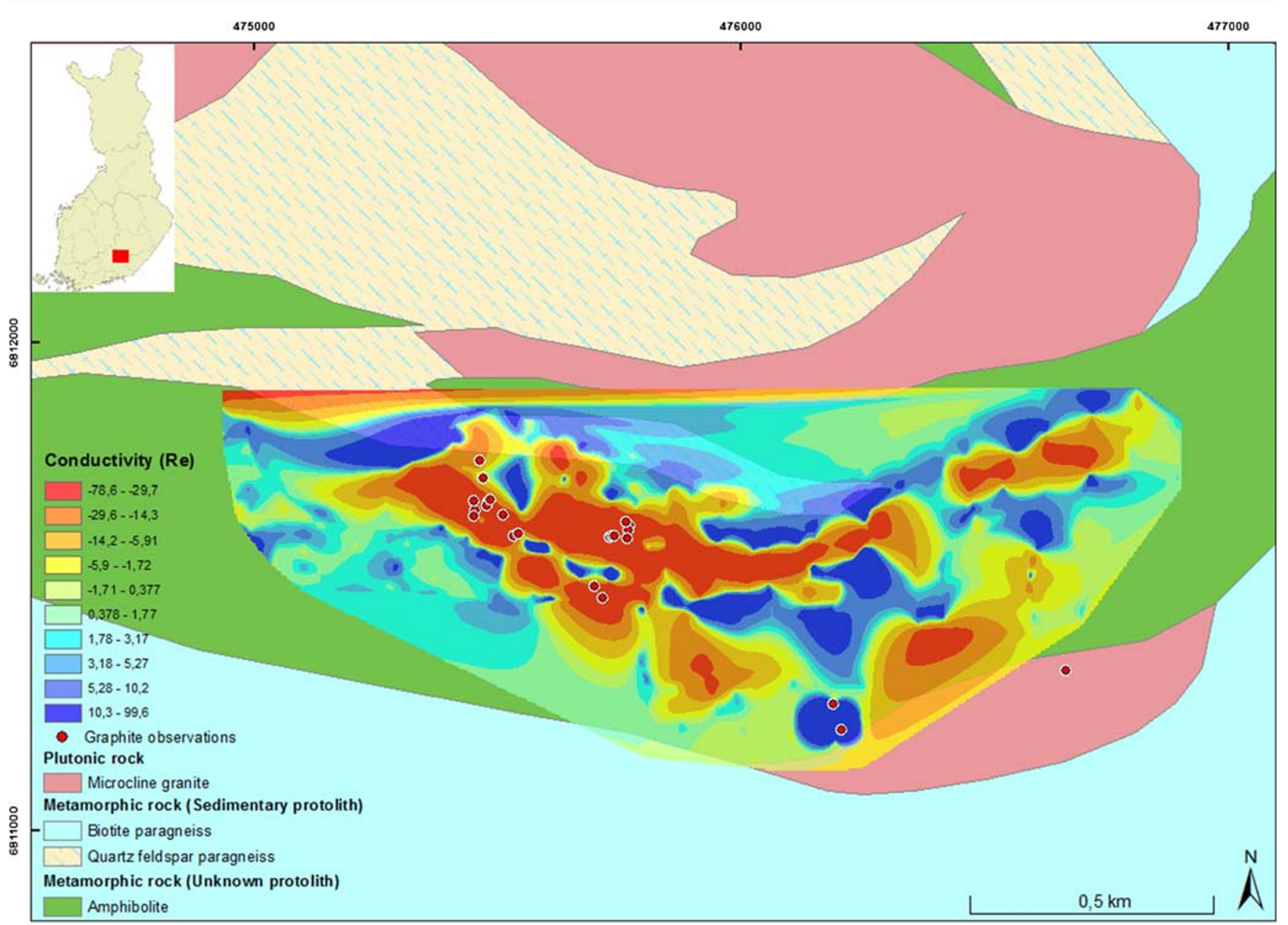

Fig. 4 Map showing results from the Slingram measurements. Very negative values indicate high conductivity (low resistivity), and positive values indicate low conductivity (high resistivity). The dots show

plagioclase + melt was found in the pseudosection at roughly 5 kbar and $740{ }^{\circ} \mathrm{C}$ (Fig. 9).

\section{Scanning electron microscopy}

SEM images show that the graphite grains appear as regular and stacked parallel flakes (Fig. 10a). Some samples are oxidized on the surfaces (Fig. 10b). No impurities in the graphite are visible in the SEM images.

\section{X-ray diffraction}

Diffraction patterns of four of the investigated samples are presented in Online Resource 2. Only small differences between the samples can be observed. All samples display a strong and narrow peak at $26.6^{\circ} 2 \theta$ and a weaker peak a $54.8^{\circ} 2 \theta$, which are related to the (002) and (004) reflections of graphite, respectively. The lack of any other graphite reflections indicates that the graphite consists of large crystalline flakes oriented in parallel with the sample holder. In addition to these peaks originating from graphite, samples 404804 and graphite observations and coincide with the conductive area. Modified from the digital geological map database of Finland (DigiKP, Geological Survey of Finland 2017)

404805 show additional peaks coming from some impurity phases. In comparison, the graphite material in sample 404806 is relatively clean, while the material from Kärpälä (sample 404812) only shows the (002) and (004) reflections from graphite.

The spacing between the graphene layers in the samples can be calculated based on Bragg's law using the diffraction angles of the (002) peak. The calculations for $\mathrm{d}(002)$ of the four samples indicate that the spacing between the layers is $0.334-0.335 \mathrm{~nm}$.

\section{Raman spectroscopy}

Raman spectroscopy results measured from liberated graphite grains show little variance (Online Resource 3a). The G band, which is a result of in-plane vibrations of aromatic carbon in the structure of graphite (Ferrari et al. 2006; Eckmann et al. 2012), is positioned at ca $1579 \mathrm{~cm}^{-1}$ in the first-order region in all spectra. This indicates that the samples consist of $\mathrm{sp}^{2}$-hybridized carbon atoms (i.e., graphene layers). The high intensity and the position of the $\mathrm{G}$ band indicate that there are 
Fig. 5 Plane-polarized image of thin section PIIPPU 2015020 (a) and PIIPPU_2015_016 (b). a Is a typical graphite-bearing quartz-feldspar gneiss, with graphite (grf) as the black nails and some irregular grains disseminated throughout the sample. b The irregular graphite grains are visible and are also mixed with chloritized biotites

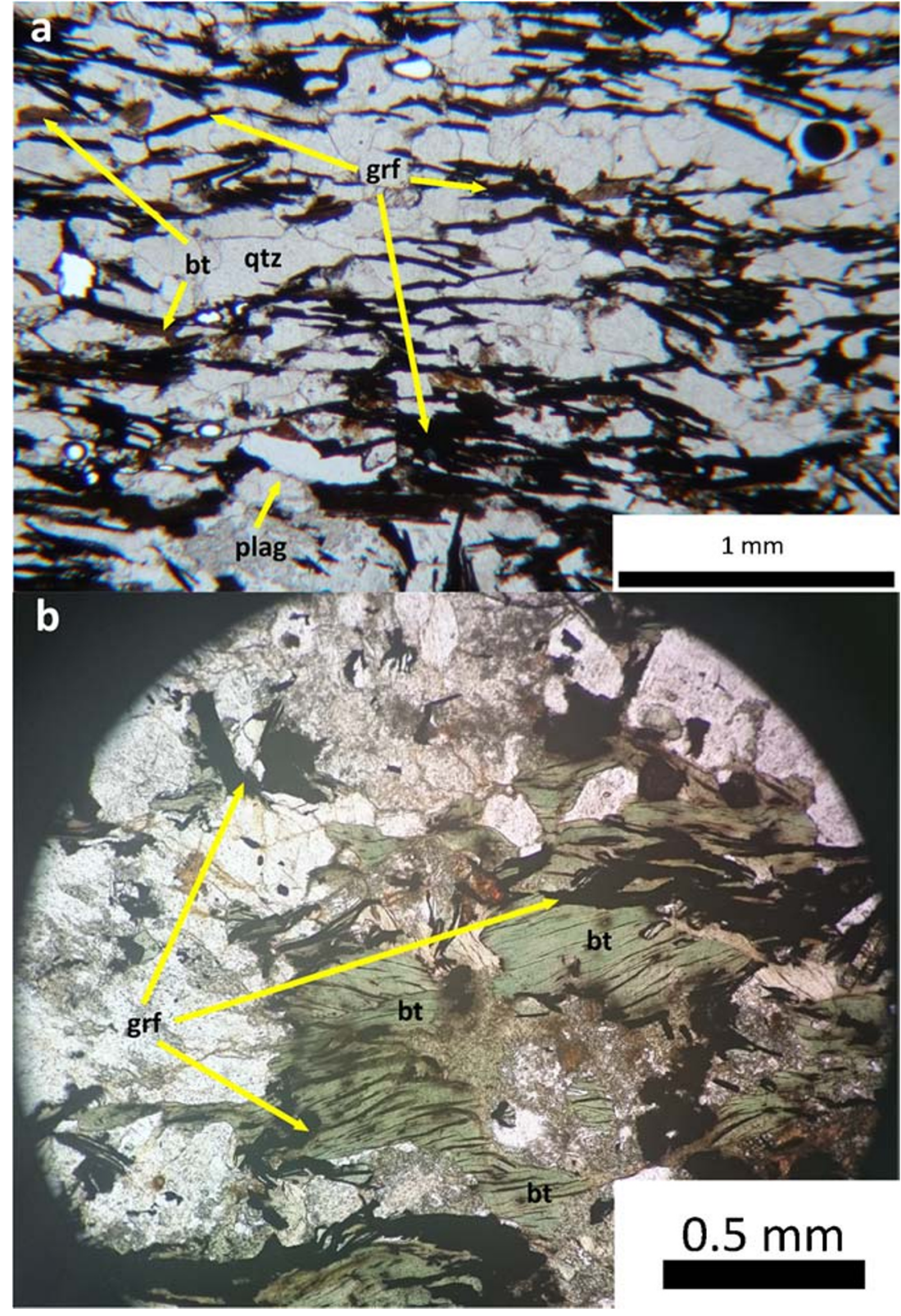

several graphene layers present in the sample (Wall 2012). In the first-order region, a number of D bands (D1, D' (D2), and D3) characterize defects in graphite, such as heteroatoms (e.g., $\mathrm{O}, \mathrm{H}$, and N) or structural defects. Samples 404804 and 404812 (sampled in Kärpälä) have weak D bands at $1360 \mathrm{~cm}^{-1}$ and $1354 \mathrm{~cm}^{-1}$, respectively (Online Resource 4). With increasing metamorphism and order in the graphite, the number and intensity of the $\mathrm{D}$ bands decrease. The secondorder region in the spectra comprises peaks of overtone and combination scattering at 2400,2700,2900, and $3300 \mathrm{~cm}^{-1}$. In the studied samples, an asymmetric $2 \mathrm{D}$ (also called $\mathrm{G}^{\prime}$ or S1) band with a shoulder facing towards lower wavenumbers is visible at ca $2723 \mathrm{~cm}^{-1}$ in all spectra which indicates that the graphite has been formed at high metamorphic grades and has many parallel stacked graphene layers in the graphite structure (Beyssac et al. 2002). All samples show a 2D' peak at ca $3247 \mathrm{~cm}^{-1}$ which is a second order of the D' (D2) band and is activated by a single-phonon intravalley scattering process (Ferrari 2007). All samples also show a small peak at ca $2440 \mathrm{~cm}^{-1}$ (called $\mathrm{G}^{*}$ and sometimes D + D"), the origin of which has been debated (Ferrari and Basko 2013). It is present both in defected and defect-free samples and is believed to originate from an intervalley process as an overtone of inplane modes (Nemanich and Solin 1979).

We measured thin sections to compare the effect of laser orientation with respect to the graphene layers in graphite sheets. The measurements made on thin sections gave different results compared with the measurements on handpicked 
Fig. 6 Garnet in sample 4048011 The alteration process from garnet to cordierite has started, which is shown as garnet not being fully isotropic. To the left in planepolarized light, and crosspolarized to the right

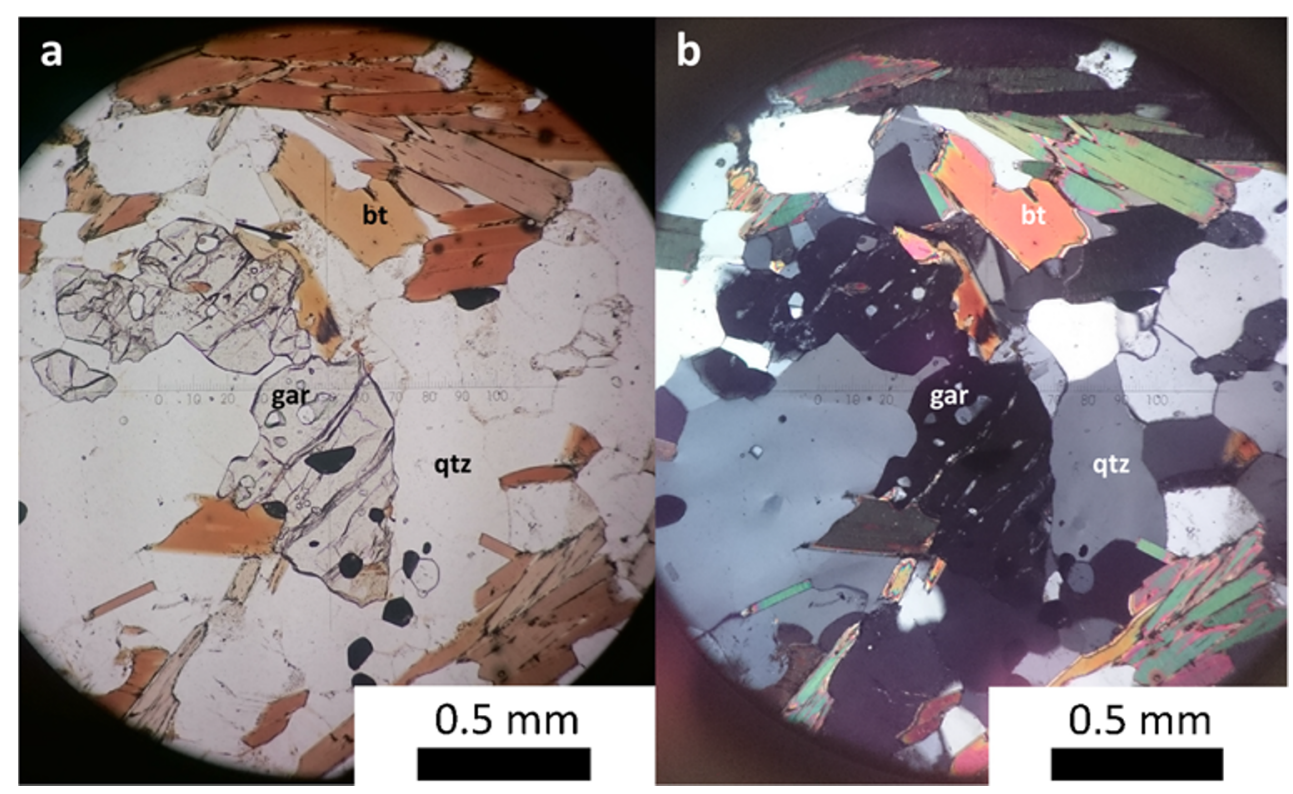

Fig. 7 Microscope images of thin section PIIPPU_2015 014d, to the right in cross-polarized light. Images a \& b show quartz banded with veins of sillimanite fibers, and $\mathbf{c} \& \mathbf{d}$ show cordierite (altered from garnet), which are the colorless grains with high relief in the center

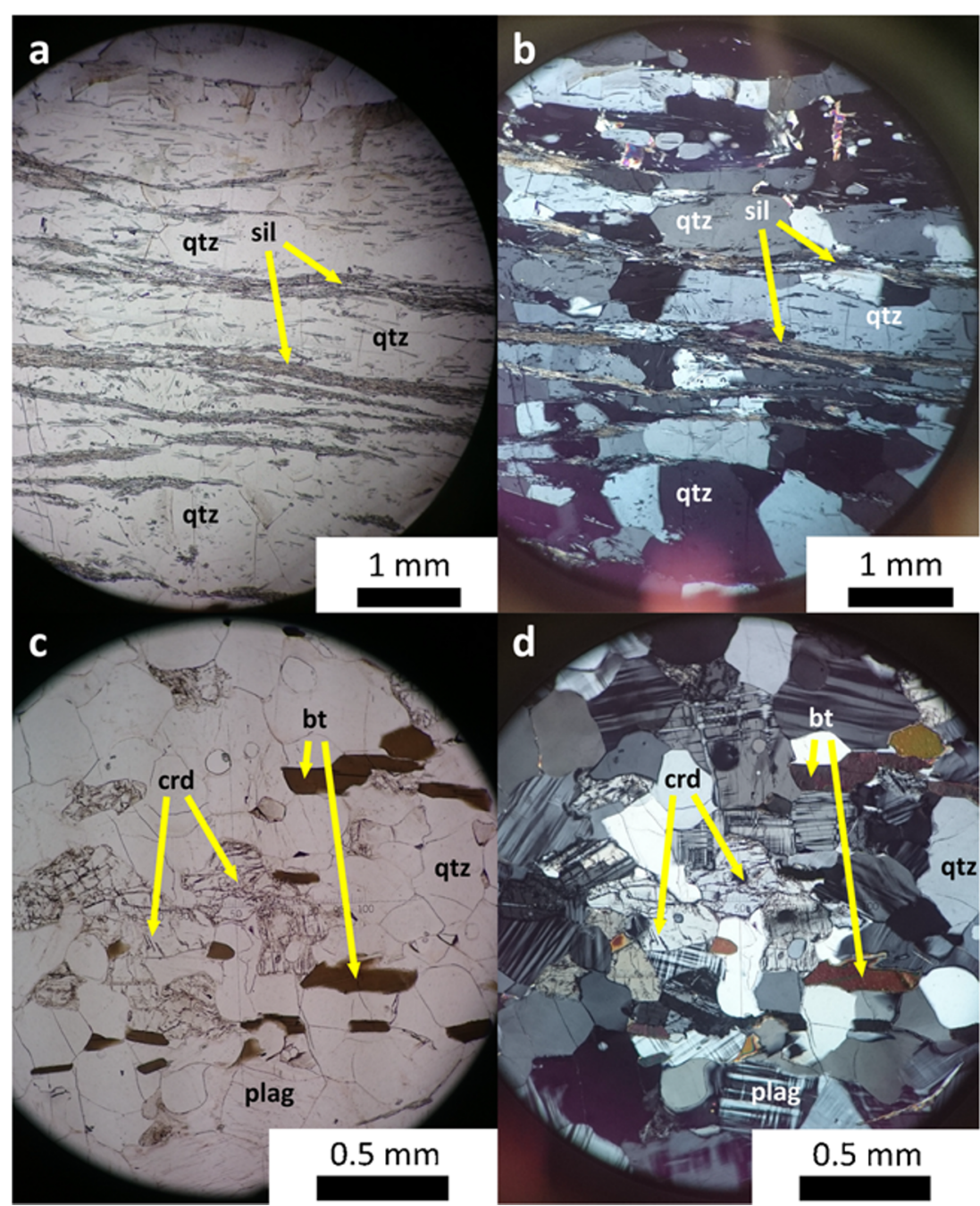


Fig. 8 Microscope images of samples 404801 (a \& b) and 404809 (c \& d), which both are amphibolites, in plane- and crosspolarized light. Upper images show brownish hornblende, and lower images show greenish hornblende together with diopside

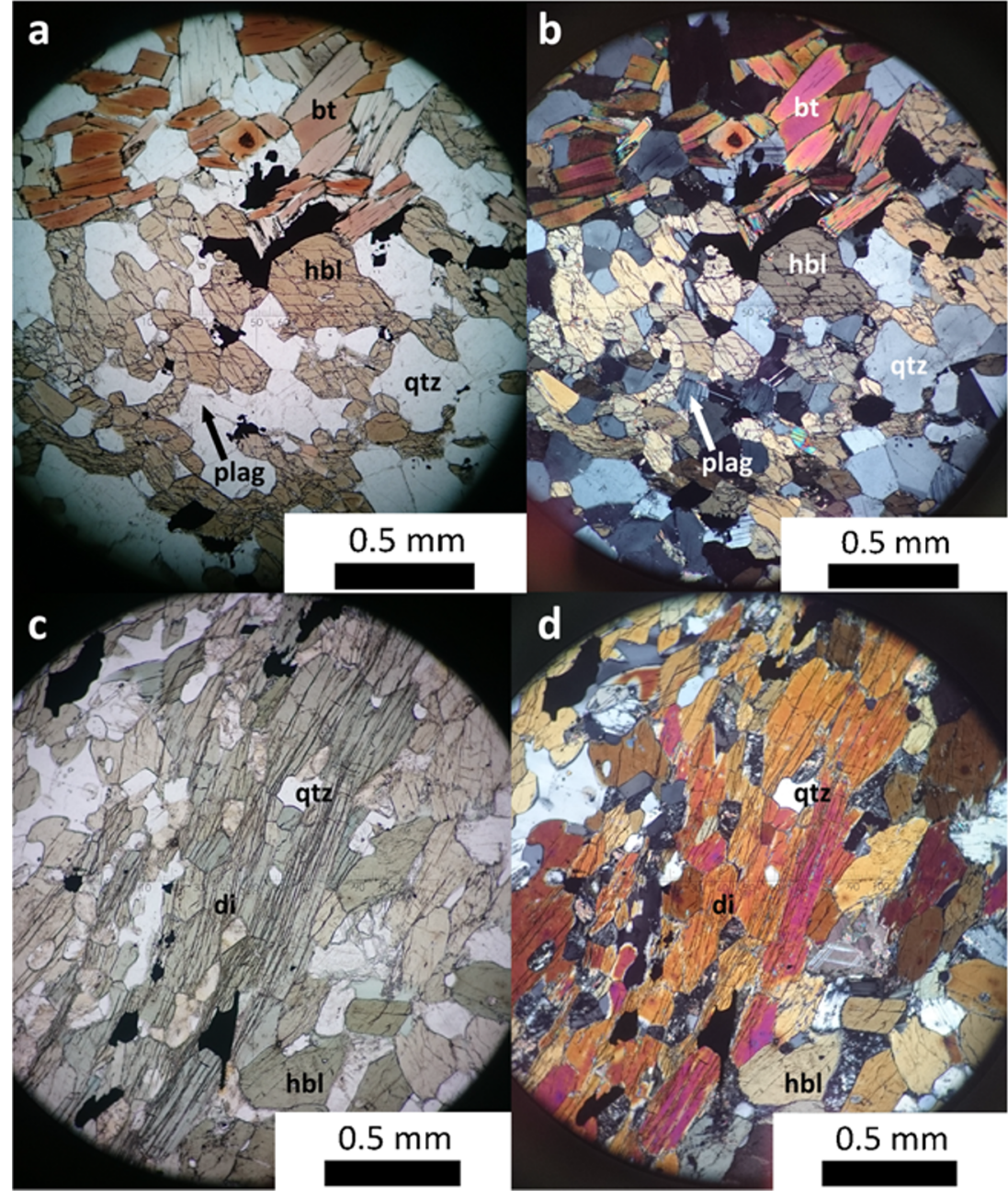

graphite grains due to the fact that the laser was directed parallel to the graphite sheets (perpendicular to the $C$-axis on graphite) and not perpendicular as during measurement of the grains. Besides the $\mathrm{G}$ and 2D bands, these spectra show several D bands, usually three (D1, before referred to as D, D2, and D3) (Online Resource 3b). The D' band can be visible in the spectra if the laser is shot at edges of the flakes, even if the rest of the sample lacks defects (Ferrari, 2007). In this way, defects from the grain boundaries become visible. The origin of the wide D3 band is out-of-plane defects such as tetrahedral carbons in the otherwise 2-dimensional graphene structure (Beyssac et al. 2002) and small crystalline size (Nemanich and Solin 1979). A new peak at $2900 \mathrm{~cm}^{-1}$ is also visible in the spectra measured from the thin sections. It originates from a combination mode of the D and 2D (D') bands (Eckmann et al. 2012).

The results from peak temperature calculations are presented in Online Resource 5. The estimates made according to Rahl et al. (2005) give temperatures between 659 and $719^{\circ} \mathrm{C}$ based on the mean values obtained from the five parallel measurements on the graphite grains from Piippumäki and Kärpälä regions. Some measurements lack the D band and give maximum temperatures for the calibration, i.e., $737^{\circ} \mathrm{C}$. Temperatures measured from thin sections were considerably lower than measurements from handpicked grains. This can be explained by the defects generated during the thin section preparation procedure and the different measurement angle in comparison with the $C$-axis on graphite.

\section{Discussion}

Discovery of strong electromagnetic anomalies and previously made studies in the Piippumäki area were the motivation for this study. These conductors appear to be caused by graphite in the bedrock, and Slingram was used to locate the graphitebearing layers more precisely (Fig. 4). The graphite appears mainly as dissemination in the quartz-feldspar gneiss and flakes up to $1 \mathrm{~mm}$ in size are visible.

The supracrustal rocks in Piippumäki were metamorphosed during the Svecofennian orogeny in low pressure granulite facies (Kähkönen 2005). A P/T determination, where wholerock chemical composition was used to construct a 
Fig. 9 Pseudosection for sample 404811 constructed in Perple_X based on the whole-rock chemical composition of the rock. The sample coincides with the stability field of biotite (bt), melt, cordierite (crd), plagioclase (pl), ilmenite (ilm), and garnet (grt) at ca 5 kbar and $740{ }^{\circ} \mathrm{C}$. No orthopyroxene (opx) was observed in this sample. The program Krita was used for drawing the pseudosection

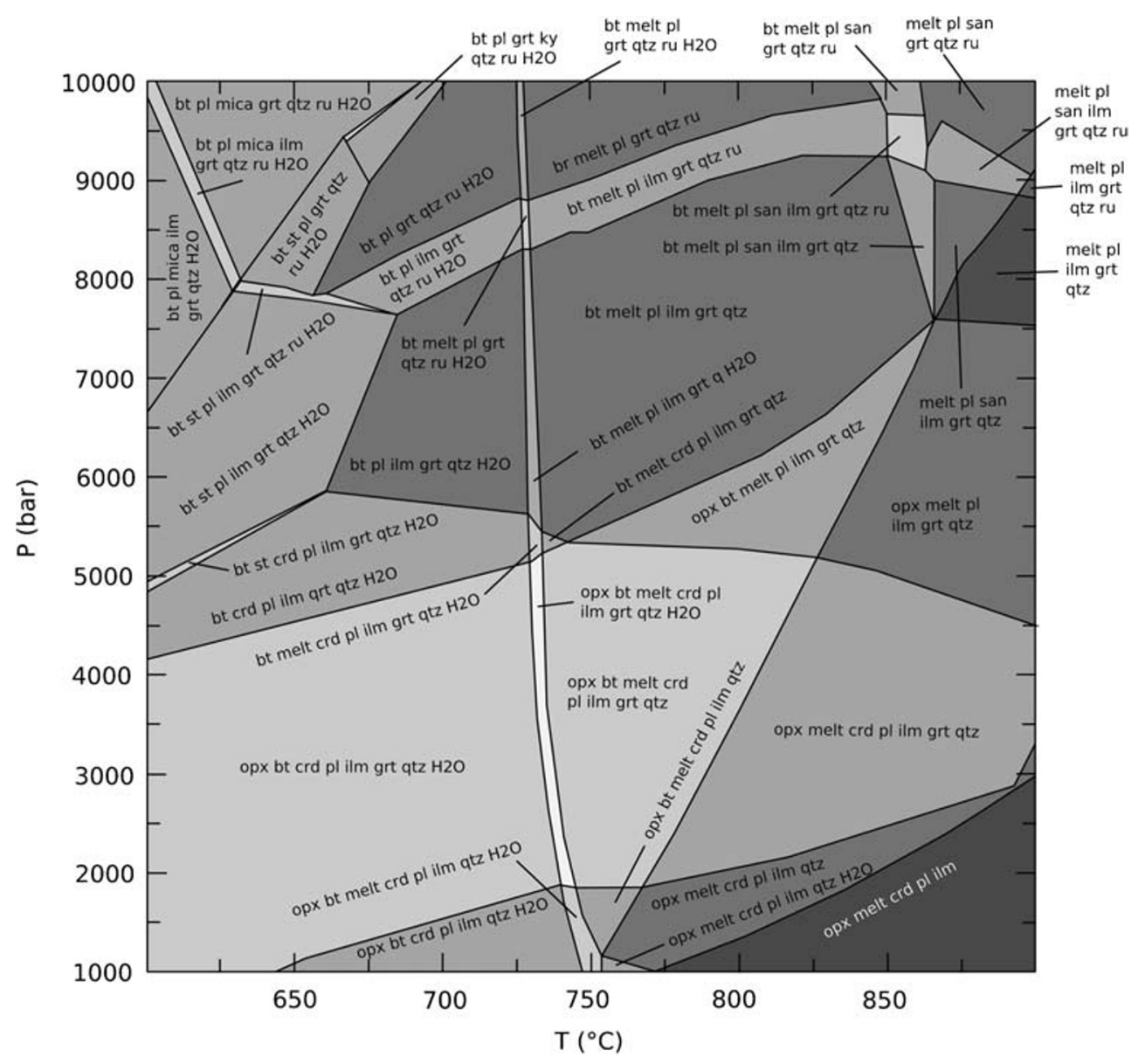

pseudosection, gave a pressure of $5 \mathrm{kbar}$ and a temperature of $740{ }^{\circ} \mathrm{C}$. This assemblage was later regressively metamorphosed to greenschist facies metamorphic conditions. The retrograde metamorphism is observed in thin sections where the paragenesis garnet - cordierite - sillimanite + melt is overprinted by chlorite - muscovite - epidote paragenesis. The peak temperature in graphite, based on the Raman spectroscopy measurements, was obtained using the calibration by Rahl et al. (2005). The obtained peak temperature of $737^{\circ} \mathrm{C}$ is for samples lacking the $\mathrm{D}$ band, but peak temperature based on the mean values is $719^{\circ} \mathrm{C}$. We argue that $737^{\circ} \mathrm{C}$ indicate the minimum temperature of the metamorphism, because this is the maximum temperature for the calibration, and measurements lacking the D band directly give this

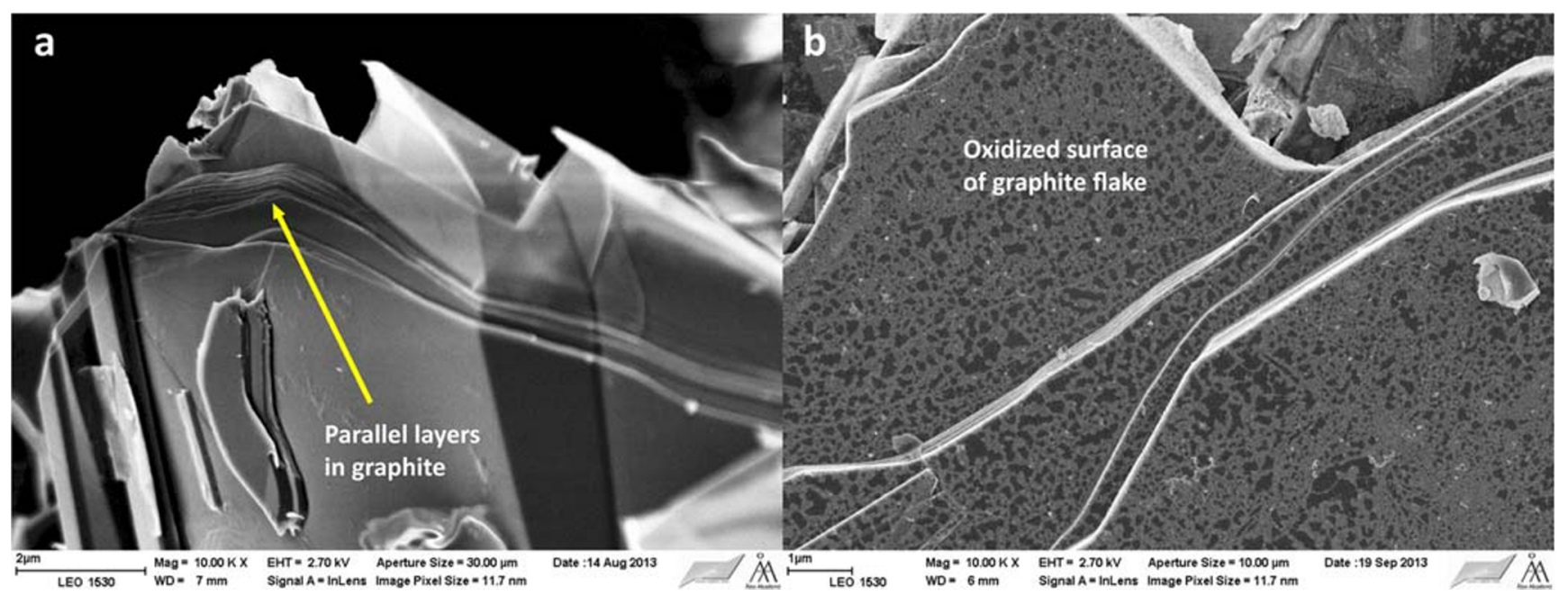

Fig. 10 SEM images showing parallel layers in graphite indicated by the arrow (a) and oxidized surfaces of graphite (b) 
temperature. The observed mineral assemblages indicate slightly higher temperatures. No Raman geothermometer estimates in this study indicate any retrograde temperatures, which points to the graphitization process being irreversible. Further research is needed to study to what extent graphite is resistant to retrograde metamorphism. This result is promising for further graphite exploration, as even retrograde metamorphic areas may still contain high-quality flake graphite deposits.

The Raman spectra obtained from graphite grains show characteristic $\mathrm{G}$ and 2D bands, and low intensity D bands. This indicates that the graphitic structure lacks defects and is highly symmetric. The weak D bands, which are visible in some samples, can arise from the laser hitting an edge in the sample, or indicate minor defects such as inorganized carbon or other defects that break up the carbon structure. Measurements made directly on graphite in thin section show several D bands in the spectra and a new peak at $2900 \mathrm{~cm}^{-1}$ compared with the spectra measured from the grains. The difference between the measurements on hand-picked grains and thin sections was apparent. The polishing of thin sections probably damaged the graphitic structure, and therefore damaged graphite sheet edges were easily recorded, resulting in these D bands (Katagiri 1988; Wopenka and Pasteris 1993). The results from measurements on separated graphite grains are therefore considered reliable.

The results from the XRD measurements imply that the graphite materials mainly consist of large and highly oriented flake-like crystals, although there are small variations between the samples. The impurity reflections in sample 404804 and 404805 probably originate from mica, quartz, and feldspar that are present in small amounts. The lack of additional peaks in sample 404812 correlates well with the fact that the carbon content in the sample from Kärpälä is higher than in those from Piippumäki. The spacing between the graphene layers in the samples is calculated to be $0.334-0.335 \mathrm{~nm}$, which is the expected distance in highly ordered graphite (Pierson 1993).

\section{Comparison with other graphite occurrences in Fennoscandia}

Similar graphite deposits as Piippumäki have been studied in Fennoscandia recently, Palosaari et al. (2016a) studied the flake graphite deposit in Vesterålen, Northern Norway, and Pearce et al. (2015) and Lynch et al. (2018) have studied the Nunasvaara graphite deposit and the surrounding geology in Northern Sweden. Graphite occurrences in Finland have been studied widely within the FennoFlakes project at Åbo Akademi University.

The flake graphite occurrence in Vesterålen has been derived from sedimentary carbonaceous material and is hosted by rocks metamorphosed in lower amphibolite granulite facies. Palosaari et al. (2016a) conclude that the graphite flakes are up to $1 \mathrm{~mm}$ in size, of high quality, and low in impurities. Results from Raman spectroscopy measurements were used to determine the peak metamorphic temperature in graphite; however, the results indicate temperatures between 575 and $620^{\circ} \mathrm{C}$ that are below the observed amphibolite-lower granulite facies (Palosaari et al. 2016a). The flake graphite in Vesterålen resembles the flake graphite in Piippumäki both being formed during the Svecofennian orogeny and being of high quality.

The graphite occurrence in Nunasvaara, northern Sweden has been studied by Pearce et al. (2015) and Lynch et al. (2016, 2018). It is Sweden's largest known metamorphic graphite occurrence with an indicated resource of approximately 5.6 Mt of $24.6 \% \mathrm{Cg}$ (Lynch et al. 2016). The graphite in Nunasvaara has been interpreted to originate primarily from organic sedimentary material, but also graphite precipitated from fluids (Pearce et al. 2015). Compared with Piippumäki, the Nunasvaara graphite occurrence is roughly of the same age. The main differences between these occurrences are in the size of the graphite flakes and the amount of graphitic carbon; the Nunasvaara graphite is microcrystalline, while the Piippumäki graphite consists of large flakes. For Nunasvaara, the peak temperature based on Raman geothermometry is between 400 and $500{ }^{\circ} \mathrm{C}$ (Pearce et al. 2015), while it peaks at $737^{\circ} \mathrm{C}$ in Piippumäki.

Nygård (2017) studied the quality of the graphite occurrence in Haapamäki, Northern Savo. There, graphite is found as flakes in graphite-bearing migmatite and metamorphosed black shale, and as massive graphite in shear zones. The area is strongly folded and the metapelitic sediments reached upper amphibolite facies during metamorphism. The Raman spectroscopy measurements indicate that the flake graphite in Haapamäki is of good quality with large flakes and only minor defects. Kujanpää (2017) studied the graphite occurrence in the Viistola-Hyypiä area, Eastern Finland, whose suitability for energy production was defined earlier (Sarapää and Kukkonen (1984a). The metamorphic degree in the area is lower amphibolite facies. This is evident as fine-grained graphite of low quality, which is the main difference compared with the graphite in Piippumäki.

\section{Conclusions}

The metamorphism in Piippumäki was of both granulite and greenschist facies. The observed granulite facies paragenesis observed (garnet - cordierite - sillimanite + melt) indicates metamorphic conditions at ca $5 \mathrm{kbar}$ and $750{ }^{\circ} \mathrm{C}$. This paragenesis is overprinted retrograde by chlorite - muscovite epidote, which indicates temperatures not higher than $400{ }^{\circ} \mathrm{C}$. The pseudosection based on whole-rock chemical composition indicates metamorphic conditions at ca $5 \mathrm{kbar}$ and $740{ }^{\circ} \mathrm{C}$. The peak temperature in graphite was determined 
from Raman spectroscopy measurements with the calibration of Rahl et al. (2005) to $737^{\circ} \mathrm{C}$, which is the highest mathematical temperature for this calibration.

Overall, the composition and metamorphic degree of the metasedimentary rocks in the Southern Finland Subprovince of the Svecofennian province are suitable for exploration of high-quality graphite. The graphite content in the Piippumäki area varies between 2.29 and $14.7 \mathrm{wt} \% \mathrm{Cg}$ (average $6.4 \mathrm{wt} \%$ $\mathrm{Cg}$ ), and the sulfur content varies between 0.06 and $1.66 \mathrm{wt} \%$ $\mathrm{S}$ (average $0.33 \mathrm{wt} \% \mathrm{~S}$ ). The graphite occurrence was located with a Slingram survey.

Based on our results, the flake graphite is of good quality with high order in the graphitic structure. The carbon structure is affected only to a minor extent, probably by O-bearing groups on the surface of graphene layers, causing defects in the graphitic structure and unorganized carbon. D bands could also be related to the laser, hitting an edge in the sample. The highly ordered structure was not affected by the retrograde metamorphism in the area, indicating that high-quality graphite deposits should also be explored within terrains that have experienced retrograde metamorphism.

Acknowledgments This research is part of the project FennoFlakes, which is a collaboration between Åbo Akademi University and the exploration company Fennoscandian Resources. We would like to thank Jukka Marmo from the Geological Survey of Finland for their input. Dr. Pentti Hölttä from the Geological Survey of Finland contributed significantly in the construction of the pseudosection and the discussion about degree of metamorphism. We direct special thanks to the fieldwork teams from Åbo Akademi University for helping with the geological mapping, sampling, and Slingram measurements. Comments by Dr. Kaisa Nikkilä, Prof. Tapani Rämö, and the reviewers significantly improved the manuscript.

Funding information Open access funding provided by Abo Akademi University (ABO). FennoFlakes has been funded by K.H. Renlund foundation and is part of the Mineral Resources and Material Substitution (MISU) program funded by the Academy of Finland.

Open Access This article is licensed under a Creative Commons Attribution 4.0 International License, which permits use, sharing, adaptation, distribution and reproduction in any medium or format, as long as you give appropriate credit to the original author(s) and the source, provide a link to the Creative Commons licence, and indicate if changes were made. The images or other third party material in this article are included in the article's Creative Commons licence, unless indicated otherwise in a credit line to the material. If material is not included in the article's Creative Commons licence and your intended use is not permitted by statutory regulation or exceeds the permitted use, you will need to obtain permission directly from the copyright holder. To view a copy of this licence, visit http://creativecommons.org/licenses/by/4.0/.

\section{References}

Ahtola T, Kuusela J (2015) Esiselvitys Suomen grafiittipotentiaalista. Archive report, 88/2015. Geological Survey of Finland
Arkimaa H, Hyvönen E, Lerssi J, Loukola-Ruskeeniemi K, Vanne J (2000) Suomen Mustaliuskeet aeromagneettisella kartalla Proterozoic black shale formations and aeromagnetic anomalies in Finland 1:1 000 000. Geological Survey of Finland

Auzanneau E, Schmidt MW, Vielzeuf D, Connolly JAD (2010) Titanium in phengite: a geobarometer for high temperature eclogites. Contrib Mineral Petrol 159:1-24

Beowulf Mining plc (2019) Strategy. https://beowulfminingcom/aboutus/strategy/ Accessed 27 October 2019

Beyssac O, Goffé B, Chopin C, Rouzaud JN (2002) Raman spectra of carbonaceous material in metasediments: a new geothermometer. $\mathrm{J}$ Metamorph Geol 20:859-871

Beyssac O, Rumble D (2014) Graphitic carbon: a ubiquitos, diverse and useful geomaterial. Elements 10:415-420

Coggon R, Holland TJB (2002) Mixing properties of phengitic micas and revised garnet-phengite thermobarometers. J Metamorph Geol 20: 683-696

DigiKP, Geological Survey of Finland (2017) Digital map database of the bedrock of Finland. https://gtkdatagtkfi/Kalliopera/indexhtml Accessed 25 October 2019

Eckmann A, Felten A, Mishchenko A, Britnell L, Krupke R, Novoselov KS, Casiraghi C (2012) Probing the nature of defects in graphene by Raman spectroscopy. Nano Lett 12:3925-3930

European Commission (2017a) Study on the review of the list of critical raw materials. Executive summary $9 \mathrm{pp}$ https:// publicationseuropaeu/en/publication-detail/-/publication/08fdab5f9766-11e7-b92d-01aa75ed71a1/language-en Accessed 21 June 2018

European Commission (2017b) Communication from the Commission to the European Parliament, the Council, the European Economic and Social Committee and the Committee of the Regions on the 2017 list of Critical Raw Materials for the EU 8pp https://eceuropaeu/ transparency/regdoc/rep/1/2017/EN/COM-2017-490-F1-ENMAIN-PART-1PDF Accessed 21 June 2018

Ferrari AC (2007) Raman spectroscopy of graphene and graphite: disorder, electron-phonon coupling, doping and nonadiabatic effects. Solid State Commun 143:47-57

Ferrari AC, Basko DM (2013) Raman spectroscopy as a versatile tool for studying properties of graphene. Nat Nanotechnol 8:235-246

Ferrari AC, Meyer JC, Scardaci V, Casiraghi C, Lazzeri M, Mauri F, Piscanec S, Jiang D, Novoselov KS, Roth S, Geim AK (2006) Raman spectrum of graphene and graphene layers. Phys Rev Lett 97:187401

Gautneb H (2016) Graphite in Fennoscandia. Presentation at Nordic Mining Day PDAC 2016 https://wwwnguno/sites/default/files/05 Gautneb_Graphitepdf Accessed 27 October 2019

Gautneb H, Tveten E (2000) Geology, exploration and characterization of graphite in the Jennestad area, Vesterålen, northern Norway. NGUBull 436:67-74

Holland T, Powell R (1996) Thermodynamics of order-disorder in minerals. 2. Symmetric formalism applied to solid solutions. Am Mineral 81:1425-1437

Holland TJB, Powell R (1998) An internally consistent thermodynamic data set for phases of petrological interest. J Metamorph Geol 16: 309-343

Holland T, Powell R (2001) Calculation of phase relations involving haplogranitic melts using an internally consistent thermodynamic dataset. J Petrol 42:673-683

Hyvönen E, Airo M-L, Arkimaa H, Lerssi J, Loukola-Ruskeeniemi K, Vanne J, Vuoriainen S (2013) Airborne geophysical, petrophysical and geochemical characteristics of Paleoproterozoic black shale units in Finland: applications for exploration and environmental studies. In: Hölttä P (ed) Geological Survey of Finland, Report of Investigation, vol 198, pp 59-61

Hölttä P, Heilimo E (2017) Metamorphic Map of Finland in bedrock of Finland at the scale 1:1000 000 - major stratigraphic units, 
metamorphism and tectonic evolution. In: Nironen M (ed) Geological Survey of Finland, Special Paper, pp 6075-6126

Kähkönen Y (2005) Svecofennian supracrustal rocks. In: Lehtinen M, Nurmi PA, Rämö OT (eds) Precambrian Geology of Finland. Dev in Precambrian Geol, vol 14. Elsevier, Amsterdam, pp 343-405

Katagiri G, Ishida H, Ishitani A (1988) Raman spectra of graphite edge planes. Carbon 26:565

Kujanpää P (2017) Kvalitetsbestämning av flakgrafit i norra ViistolaHyypiäområdet, östra Finland. Master's thesis. Åbo Akademi University, Turku $60 \mathrm{pp}$

Leading Edge Materials (2018) Woxna graphite. https:// leadingedgematerialscom/woxna-graphite/ Accessed 27 October 2019

Lynch EP, Hellström FA, Huhma H (2016) The Nunasvaara graphite deposit, northern Sweden: new geochemical and $\mathrm{U}-\mathrm{Pb}$ zircon age results from the host greenstones. Conference abstract, Nordic Geological Winter Meeting 13-15 January 2016, Helsinki http:// www.geologinenseura.fi/winter meeting/abstracts newnum pdf/ S2_1_365.pdf Accessed 27 October 2019

Lynch EP, Hellström FA, Huhma H, Jönberger J, Persson P-O, Morris GA (2018) Geology, lithostratigraphy and petrogenesis of c. $2.14 \mathrm{Ga}$ greenstones in the Nunasvaara and Masugnsbyn areas, northernmost Sweden. In: Bergman S (ed) Geology of the Northern Norrbotten ore province, northern Sweden, Rapporter och meddelanden, Sveriges geologiska undersökning, vol 141, pp 19-77

Mineral Deposits and Exploration (n.d.) Geological Survey of Finland. https://gtkdata.gtk.fi/mdae/index.html Accessed 25 October 2019

Nemanich RJ, Solin SA (1979) First- and second-order Raman scattering from finite-size crystals of graphite. Phys Rev B 20:392-401

Newton RC, Charlu TV, Kleppa OJ (1980) Thermochemistry of the high structural state plagioclases. Geochim Cosmochim Acta 44:933941

Nironen M (2017) Guide to the geological map of Finland - bedrock 1:1 000 000. In: Nironen M (ed) Bedrock of Finland at the scale 1:1 000 000 - major stratigraphic units, metamorphism and tectonic evolution. Geol Surv Finland Spec Pap, vol 60, pp 41-76

Nironen M, Kousa J, Luukas J, Lahtinen R (2016) Geological map of Finland - bedrock 1:1 000 000. Geological Survey of Finland

Northern Graphite (2019) Graphite pricing. http://northerngraphitecom/ about-graphite/graphite-pricing/ Accessed 20 October 2019

Nurmela P (1989) Katsaus Suomen grafiittiesiintymiin. Report M81/ 1989/1, Geological Survey of Finland

Nygård H (2017) Kvalitetsbestämning av flakgrafit i Haapamäki, Leppävirta, Norra Savolax. Master's thesis. Åbo Akademi University, Turku

Palosaari J, Latonen R-M, Smått J-H, Blomqvist R, Eklund O (2016a) High-quality flake graphite occurrences in a high-grade metamorphic region in Sortland, Vesterålen, northern Norway. Nor J Geol 96: $19-26$

Palosaari J, Eklund O, Raunio S, Lindfors T, Latonen R-M, Peltonen J, Smått J-H, Kauppila J, Lund, S, Sjöberg-Eerola P, Blomqvist R, Marmo J (2016b) FennoFlakes: a project for identifying flake graphite ores in the Fennoscandian shield and utilizing graphite in different applications. Geophysical Research Abstracts 18. EGU General Assembly 2016

Pearce JA, Godel BM, Thompson M (2015) Microstructures and mineralogy of a world-class graphite deposit. Society of Economic
Geologists, Annual Conference 2015 Hobart, Australia. Program and abstracts

Pierson HO (1993) Handbook of carbon, graphite, diamond and fullerenes. Noyes Publications, Saddle River

Puustinen K (2003) Suomen kaivosteollisuus ja mineraalisten raakaaineiden tuotanto vuosina 1530-2001, historiallinen katsaus erityisesti tuotantolukujen valossa Geological Survey of Finland Archive report, M101/2003/3 Web-version: http://weppigtkfi/ aineistot/kaivosteollisuus/Grafiittikaivoksethtm Accessed 20 June 2018

Rahl JM, Anderson KM, Brandon MT, Fassoulas C (2005) Raman spectroscopic carbonaceous material thermometry of low-grade metamorphic rocks: calibration and application to tectonic exhumation in Crete, Greece. Earth Planet Sci Lett 240:339-354

Rankama K (1948) New evidence of the origin of pre-Cambrian carbon. Bull Geol Soc Am 59:399-416

Rønning JS, Gautneb H, Larsen BE, Knežević J, Baranwal VC, Elvebakk H, Gellein J, Ofstad F, Brönner M (2018) Geophysical and geological investigations of graphite occurrences in Vesterålen and Lofoten, Northern Norway 2017. NGU report 2018.011. Geological Survey of Norway

Sarapää O, Kukkonen I (1984a) Grafiittitutkimukset Kiihtelysvaaran Hyypiässä vuosina 1981-1983. Report M 81/4241/-84/2. Geological survey of Finland

Sarapää O, Kukkonen I (1984b) Grafiittiesiintymistä ja niiden energiakäyttömahdollisuuksista. Report M 81/1984/3. Geological survey of Finland

Simonen A (1982) Mäntyharjun ja Mikkelin kartta-alueiden kallioperä. Summary: pre-quaternary rocks of the Mäntyharju and Mikkeli map-sheet areas. Geological map of Finland 1:100 000, explanation to the maps of pre-quaternary rocks, sheets 3123 and 3142 . Geological Survey of Finland

Tajcmanová L, Connolly JAD, Cesare B (2009) A thermodynamic model for titanium and ferric iron solution in biotite. J Metamorph Geol 27: $153-164$

Waldbaum DR, Thompson JB (1968) Mixing properties of sanidine crystalline solutions: 2. Calculations based on volume data. Am Mineral 53:2000-2017

Wall M (2012) Raman spectroscopy optimizes graphene characterization. Adv Mater Process 170:35-38

White RW, Powell R, Holland TJB, Worley BA (2000) The effect of TiO2 and $\mathrm{Fe} 2 \mathrm{O} 3$ on metapelitic assemblages at greenschist and amphibolite facies conditions: mineral equilibria calculations in the system K2O-FeO-MgO-A12O3-SiO2-H2O-TiO2-Fe2O3. J Metamorph Geol 18:497-511

White RW, Powell R, Holland TJB (2001) Calculation of partial melting equilibria in the system Na2O-CaO-K2O-FeO-MgO-A12O3-SiO2H2O (NCKFMASH). J Metamorph Geol 19:139-153

Wopenka B, Pasteris JD (1993) Structural characterization of kerogens to granulite-facies graphite: applicability of Raman microprobe spectroscopy. Am Mineral 78:533-557

Publisher's note Springer Nature remains neutral with regard to jurisdictional claims in published maps and institutional affiliations. 